\title{
The relationship among technological creativity, self-efficacy and entrepreneurial intentions of selected South African university of technology students
}

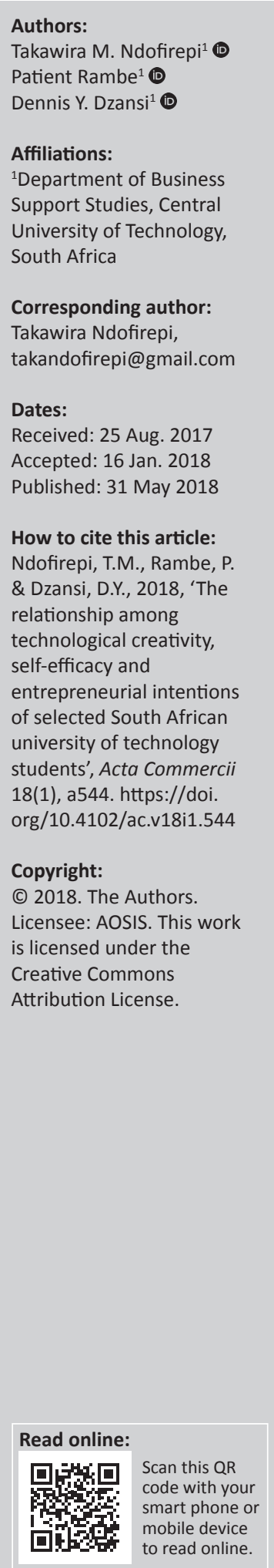

Orientation: The purpose of this study is to explore the relationship among technological creativity, self-efficacy and entrepreneurship intentions of university students in an emerging economy context.

Research purpose: This study explores how technological creativity is linked to self-efficacy and entrepreneurial intentions.

Motivation of the study: African countries are pervaded by subdued imagination that breeds survivalist entrepreneurship, which is bereft of innovation. This reality calls for the input of technological creativity to innovative entrepreneurship. Although results from contemporary research acknowledge the explanatory effect of technological creativity on entrepreneurial intentions, they under-explore the mechanism of the relationship, particularly in sub-Saharan Africa, hence this study.

Research design, approach and method: Using a quantitative approach and cross-sectional survey design, a self-completion questionnaire was administered to 130 students who had undergone a compulsory entrepreneurship course at a South African university of technology. The study employed Pearson's correlation test, regression analysis and the bootstrapping procedure to assess the mediation effects and test the different hypothesised relationships.

Main findings: The findings revealed that self-efficacy fully mediated the influence of technological creativity on entrepreneurship intentions.

Practical and managerial implications: The results of the study stress the importance of considering psychological aspects, such as technological creativity and self-efficacy, in the evaluation of ways that can be used to effectively foster the entrepreneurial intentions of students undergoing entrepreneurship education.

Contribution or value-add: The results authenticated psychological frameworks as guiding tools to understanding the intentional component of planned entrepreneurship activity. The study added further knowledge by exploring a previously untested relation between technological creativity and self-efficacy to unravel the complexity of entrepreneurial intentions among tertiary students.

\section{Introduction}

Creativity has become a central issue in attempts at understanding entrepreneurship behaviour within the new global economy (Camacho-Miñano \& Del Campo 2017; Rumble \& Minto 2017). Such an association builds upon Schumpeter's (1934) portrayal of entrepreneurship as creativityand innovation-driven. Creativity is credited for its role in idea generation (Toubia \& Netzer 2016), opportunity recognition (Martin \& Wilson 2016), the development of new products and services (Cui \& Wu 2017; Dean, Griffith \& Calantone 2016) and establishment of new business entities (Lund, Byrge \& Nielsen, 2017).

Arguably, creativity, through its influence on entrepreneurial behaviour, has a greater role to play in developing countries given the prevalence of youth formal unemployment, poverty and social iniquities in such contexts (Bhalla \& Lapyre 2016). Scholars (Asah, Fatoki \& Rungani 2015; Cant \& Wiid 2013; Maduku, Mpinganjira \& Duh 2016) believe in the potency of entrepreneurship as one of the strategic responses to the 'triple challenges' of poverty, unemployment and social inequality in the country. It is postulated that creativity underlies the establishment of new 
businesses that will, in turn, need skilled labour to operate (Lund et al. 2017). At the same time, it drives the creation and the introduction of innovative products in the existing businesses, enhancing their competitive advantage and growth potential in the process. Consequently, the creativity embedded in entrepreneurial individuals is a leading contributing factor to the promotion of economic growth, the widening of consumer product choices, job creation and a transformation of the industry and businesses (Ferreira et al. 2017). The bottom line is that creativity affords to countries the means to mitigate the effects of the socioeconomic challenges bedevilling them. In addition, the accumulation of environmentally fitting technology and skills inventories augments the likelihood of business endurance (Rambe, Ndofirepi \& Dzansi 2015). Yet, empirical entrepreneurial activity among South Africa's adult population is significantly lower in comparison to other sub-Saharan African countries (Herrington, Kew \& Mwanga 2017; Malebana \& Swanepoel 2015).

Although research focus towards creativity has increased of late, a review of entrepreneurship literature reveals that there is relatively limited theoretical work relating to technological creativity and with regard to its association with the entrepreneurial intentions of individuals in general. Ndofirepi (2016) proposes that this under-researched form of creativity is key to the resurgence of opportunity-driven entrepreneurship activity in the contemporary world. Technological creativity can be understood as 'the willingness on one's part to experiment with new ideas with the objective of solving everyday problems' (Rambe et al. 2015:577). Mokyr (1992:3) conceives technological creativity as 'novel ways to apply knowledge so as to improve production techniques, a shift outward of the productivity curve'. The concept differs from general creativity, which stresses the generation of new ideas and knowledge, and requires boldness and imagination (Charyton 2008) in that the outcomes of technological creativity are 'new or original ideas, insights, restructurings, inventions or artistic objects, which are accepted by experts as being of scientific, aesthetic, social or technological value' (Wyse \& Spendlove 2007:182). Therefore, the focus of technological creativity is on the improvement of specific production mechanisms and problem solving in society rather than just generation of new knowledge. These qualities make technological creativity a subject of research interest given the socio-economic challenges prevailing in the spatial context of this study.

The results from pilot studies conducted by Rambe, Ndofirepi and Dzansi (2016) and Ndofirepi (2016), which were based on Ajzen's (1991) Theory of Planned Behaviour, reveal a positive correlation between technological creativity and entrepreneurship intentions. These outcomes substantiate those from earlier studies that tie creativity in general with the students' willingness to engage in entrepreneurship in the future (Berglund \& Wennberg 2006; Hamidi, Wennberg \& Berglund 2008; Zampetakis 2008; Zampetakis et al. 2011; Zampetakis \& Moustakis 2006).
In spite of the existing research studies, little is known about the mechanism through which technological creativity affects entrepreneurship intention. The purpose of this article is to further our theoretical understanding of the relationship between technological creativity and entrepreneurial intention by incorporating a major psychological component, namely self-efficacy, into the relationship. Some entrepreneurship research acknowledges the positive and significant effect of self-efficacy on entrepreneurial intentions of individuals (Ajzen 1991; Krueger 2000; Krueger Jr \& Brazeal 1994; Shapero \& Sokol 1982). This view is supported by other findings from numerous recent studies carried out across the world (Nowiński et al. 2017; Piperopoulos \& Dimov 2015; Solesvik 2017; Urban 2015; Wang et al. 2016). Similarly, some studies suggest positive and significant relationships between general creativity or technological creativity and entrepreneurial intentions (Biraglia \& Kadile 2017; Rambe et al. 2016; Zampetakis 2008; Zampetakis et al. 2011). Because self-efficacy is linked to 'task effort and performance, persistence, resilience in the face of failure, effective problem solving and selfcontrol' (Yu 2013:184), we posit that any entrepreneurial intentions arising from one's willingness to experiment with new ideas (technological creativity) is mediated by one's confidence in one's ability to successfully execute a task (selfefficacy). Hence, this study investigates the link between technological creativity, self-efficacy and entrepreneurship intentions of students undergoing a compulsory, crossdiscipline and semester-long entrepreneurship course at a South African university of technology. Although the two independent variables (technological creativity and selfefficacy) are connected individually to entrepreneurship intentions, no scientific study, to the researchers' knowledge, has so far explored how the three variables are associated. This article, therefore, provides a theoretical framework to address this knowledge gap.

We hypothesise that self-efficacy mediates the effect of technological creativity on the entrepreneurship intentions of students exposed to entrepreneurship education. Thus, the main objective of this study is to establish if self-efficacy influences the relationship between technological creativity and entrepreneurship intention. To fulfil this research objective, we investigated if technological creativity, selfefficacy and entrepreneurial intentions are correlated. We also ascertained whether technological creativity, in the presence of some control factors, predicts entrepreneurial intention.

The remainder of the article is organised as follows. The first section reviews the existing literature on self-efficacy, technological creativity and entrepreneurship intention. The second section outlines the research design and methodology employed to test the hypotheses. The study's findings are then provided and the article concludes with a discussion on the study's implications for practice and theory.

\section{Literature review}

This section reviews the literature on technological creativity, self-efficacy and entrepreneurial intention. 


\section{Technological creativity}

The first serious discussions and analysis of the concept of technological creativity in the entrepreneurship context emerged in 2015 (Rambe et al. 2015). Technological creativity is derived from a combination of two variables, that is, creativity which refers to the production of novel and useful ideas by an individual or small group of individuals working together' (Amabile \& Pratt 2016:158) and technology which relates to any techniques, skills, methods and processes that are used to solve real-life problems (Pacey 2014). For the current study, technological creativity is taken to mean the ability to come up with new ideas, skills, methods, techniques and processes that solve practical problems. The key difference between technological creativity and general creativity is in technological creativity's practical purpose (Cropley \& Cropley 2010). Thus, the reality that technological creativity often generates the innovations and inventions makes it a key factor in the creation of business and societal value (Ndofirepi 2016).

The rapid and often evolutionary changes that characterise the 21st-century entrepreneurial environment create numerous market challenges for both nascent and established business (Becherer \& Helms 2016). For instance, the octane of rapid changes results in the emergence of new customer needs and competition platforms (Chuang \& Huang 2016). As a result, the tenure of human resources endowed with the appropriate skills inventories and technological creativity is fundamental to the firms' performance (Lin \& Nabergoj 2014). The innovations that emanate from technological creativity enhance business organisations' competitive advantages and the probability of survival (Prajogo 2016). Thus, technological creativity capabilities afford businesses the opportunity to generate different solutions to challenges and identify new market opportunities as a strategic tool. In the current study, we hypothesise that:

$\mathbf{H}_{1}$ : Technological creativity is positively correlated to selfefficacy and entrepreneurial intention.

\section{Self-efficacy}

A brainchild of Bandura (1970), self-efficacy refers to the belief and assurance in one's abilities to follow and attain a particular objective (Botha \& Bignotti 2016; Bullough, Renko \& Myatt 2014; Sweida \& Reichard 2013). This concept is often equated with perceived behavioural control discussed by Ajzen (1991) and with perceived feasibility variables explained by Shapero and Sokol (1982). Nevertheless, several studies positively associate self-efficacy with decisions that initiate and grow business ventures in the area of entrepreneurship (Hatak \& Snellman 2017; Hsu, Wiklund \& Cotton 2017; McGee \& Peterson 2017; Utami 2017). Thus, predetermined undertakings, such as starting a new business entity, introducing a new product or pursuing new market opportunities, depend on an individual's self-efficacy. Frequently, the decision of whether to engage in entrepreneurship depends on the strength of one's entrepreneurial self-efficacy. In other words, a difference in the strength of individual self-efficacy distinguishes potential entrepreneurs from non-entrepreneurs.

Personalities with higher levels of self-efficacy are adventurous and disposed towards carrying out complicated tasks (Ahuja 2016). In contrast, those with lower levels of selfefficacy are reluctant to pursue uncertain undertakings. The uncertainty and hazard concomitant to the contemporary business world present an environment that only the confident can endure (Dinis et al. 2013). In the contemporary environment, characterised by the strong need for innovative and growth-oriented entrepreneurs (Griffiths et al. 2012), possession of a high degree of entrepreneurial self-efficacy is a valuable asset. It is thus intriguing to explore the extent of entrepreneurial self-efficacy among learners undertaking entrepreneurship education who have to decide on whether to take up formal occupations or entrepreneurial vocations. The researchers acknowledge that entrepreneurial selfefficacy can be acquired through entrepreneurship education (Zimbroff, Taylor \& Houser 2016) and one's creativity levels (Ng \& Lucianetti 2016). Hence, it is hypothesised that the levels of one's technological creativity affect self-efficacy and, subsequently, entrepreneurial intention.

\section{Entrepreneurial intention}

Entrepreneurial intention refers to an individual's inclination to participate in new venture creation in the future (Thompson 2009). Results from numerous empirical studies show that individuals demonstrating strong intentions towards certain activity eventually partake in the specific behaviour (Fayolle, Liñán \& Moriano 2014; Liñán \& Fayolle 2015). In fact, evidence from some studies demonstrates that entrepreneurial intentions account for at least $30 \%$ of the change in actual entrepreneurship behaviour (Liñán \& Chen 2009; Van Gelderen et al. 2008). This observation is corroborated by evidence from other contexts of application including voting behaviour, birth control and consumer behaviour (Ajzen 2015). Hence, the above observations suggest that intentions exert the strongest degree of influence on human behaviour.

Thompson (2009) laments the absence of a consistently reliable and valid measuring scale for entrepreneurial intentions. This is in spite of this construct being a research niche area as reflected by the numerous studies based on it. For Thompson (2009), the lack of a valid and reliable scale undermines the evolution of entrepreneurship intentionsbased research as an independent field of study. Furthermore, this weakness heightens claims about a lack of theoretical sophistication and methodological rigour in entrepreneurship research (Fayolle 2013; McElwee \& Atherton 2005). Notwithstanding the scholarly apprehensions expressed in the ensuing paragraph, the existence of robust evidence of intentions as a strong predictor of premeditated actions is possibly of interest to entrepreneurship educators and policymakers in South Africa alike. This is because of the noteworthy high unemployment rate in the country which currently stands at 27\% (Statistics South Africa 2017), as well 
as the frequency of post-entry failure of new business start-ups (Herrington et al. 2017). Apparently, there is a need for well-considered policy interventions that inspire the young people of South Africa to partake and thrive in entrepreneurship. Consequently, it is important to fully comprehend the factors that affect a person's entrepreneurial intentions.

In spite of studies that proclaim the significant influence of individual cognition, personalities, personal circumstances, micro- and macro-environmental factors on such intentions (Dinis et al. 2013; Ferreira et al. 2012; Hattab 2014; Nabi, Holden \& Walmsley 2010; Nabi et al. 2017), a comprehensive approach that emphasises the integrated influence of these factors on entrepreneurial intentions is non-existent. Thus, the entrepreneurial intention concept is not fully explained and requires further examination for its theoretical validation and development. Nonetheless, the extant literature on entrepreneurship reveals various theories on entrepreneurship intentions with the most applied being Theory of Planned Behaviour by Ajzen (1991), Theory of the Entrepreneurial Event by Shapero and Sokol $(1982)$ and Theory of Entrepreneurial Ideas by Bird $(1988,2015)$. According to Ajzen (1991), intention and subsequent behaviour are a result of attitudinal, normative and behavioural beliefs. However, the relationship is mediated by other exogenous and endogenous variables. Separately, the model put forth by Shapero and Sokol (1982) proposes that entrepreneurship intentions are formed by perceived desirability, feasibility and propensity to act. Finally, Bird's (1988) theory claims that entrepreneurship intentions are influenced by a person's rational and intuitive thoughts that take place in different personal and sociopolitical settings.

Over the years, attempts at solidifying the theoretical foundations of entrepreneurial intentions research have seen some studies attempting to blend different theories in a single study. For instance, the meta-analytic study by Schlaegel and Koenig (2014) which tested and integrated the Theory of Planned Behaviour and the Entrepreneurial Event model revealed that the integrated model affords additional explanatory power and more comprehensive understanding of the process through which entrepreneurial intent evolves. Other studies that have also successfully integrated models include those by Krueger, Reilly and Carsrud (2000) and Drnovsek and Erikson (2005), collectively giving an in-depth understanding of the formation of entrepreneurial intentions. These results have made meaningful contributions towards the shaping of developmental and educational policies on entrepreneurship.

Overall, research on entrepreneurial intentions has grown, focusing on different nuances. Fayolle and Liñán (2014) suggest that future studies on entrepreneurial intentions should dwell on the concept in different entrepreneurial contexts; for example, corporate entrepreneurship intention, social entrepreneurship intention, academic entrepreneurship intention and family entrepreneurship intention - if the research field is to further grow. In addition, Liñán and
Fayolle (2015) carried out a systematic review of 406 research papers on entrepreneurship intentions published between 2004 and 2013 and revealed the following research strands: theoretical and methodological aspects of the core entrepreneurial intentions modes, the role of personal variables in shaping entrepreneurship intentions, the relationship between entrepreneurship education and entrepreneurial intentions, the influence of context and institutions on the configuration of entrepreneurial intentions as well as the entrepreneurial process and entrepreneurship intention-behaviour link. In spite of the research area being a mature field of study, Singh, Verma and Rao (2017) contend that consensus on the factors that influence entrepreneurial intentions is improbable (Singh et al. 2017). To narrow this gap, an area of research interest would be to explore the influence of personal-level variables such as technological creativity on entrepreneurial intention.

Although the above-presented theories offer broad explanations concerning the evolution of entrepreneurship intentions, it is necessary for us to appreciate other dynamics that form this variable. This does not only help to augment current intervention measures that seek to promote entrepreneurial activity but could also prevent the underrepresentation of some relevant factors in entrepreneurship intention theories. Therefore, we speculate that technological creativity can directly or indirectly influence entrepreneurship intention.

\section{Link between technological creativity, self-efficacy and entrepreneurship intention}

As noted in the introduction, previous studies show that the associations between creativity and entrepreneurship intention, as well as self-efficacy and entrepreneurship intention, have thus far been investigated independently. Hamidi et al. (2008) argue that the creativity intensities of tertiary education students are positively connected to entrepreneurship intentions. This conclusion substantiated findings from the study by Zampetakis and Moustakis (2006) on the influence of creativity on the entrepreneurship intentions of students. Using samples of undergraduate students from particular Greek universities, the study discovered that belief in one's creative abilities and a family setting that supports creative thinking positively influenced the degree of entrepreneurship intentions. Zampetakis et al. (2011) studied the influence of creativity on the entrepreneurship intentions of business school students at a British university and findings revealed a positive relation between creativity and entrepreneurship intentions, with this relationship having been moderated by the students' attendance of an entrepreneurship course. To the researchers' knowledge, only Ndofirepi (2016) has studied the association between technological creativity and entrepreneurship intentions.

Extant literature demonstrates that there is a significant relationship between self-efficacy and entrepreneurship intentions of respondents (Arora, Haynie \& Laurence 2013; 
Bullough et al. 2014; Campo 2010; Drnovšek, Wincent \& Cardon 2010; Malebana 2014; Malebana \& Swanepoel 2015; Urban, Van Vuuren \& Owen 2008). While the results of most studies propose a direct relationship between the variables, some studies adopt a different approach, focusing on the indirect (mediating or moderating) influence of self-efficacy on entrepreneurial intentions of respondents. For instance, a study conducted by Peng, Lu and Kang (2012) on the relationship between entrepreneurial self-efficacy and entrepreneurial intention among Chinese college students reveals that self-efficacy mediated the relationship between the personality factors and entrepreneurial intentions of respondents. In a study exploring the entrepreneurial intentions of business students in Croatia, Pfeifer, Šarlija and Zekić Sušac (2016) observed that the strength of one's entrepreneurial identity aspiration and entrepreneurial self-efficacy are significant predictors of entrepreneurship intentions. At the same time, the two constructs mediated the relationship between a number of personal factors, contextual factors, education and entrepreneurship intention. The findings from the preceding studies gel with those from earlier studies that suggest a direct positive and significant effect of entrepreneurial self-efficacy on entrepreneurial intentions. Because self-efficacy can 'produce the belief in one's capability to mobilize the motivation, cognitive resources, and courses of action needed to exercise control over events in one's life' (Mauer, Neergaard \& Linstad 2009:237), we posit that there is a positive relationship between self-efficacy and entrepreneurial intentions. It can be hypothesised that:

$\mathbf{H}_{2}$ : There is a positive relationship between self-efficacy and entrepreneurial intentions.

In addition, although the relationships between students' technological creativity and entrepreneurship intentions as well as self-efficacy and entrepreneurship intention have been studied separately, no study carried out in South Africa links the three factors in a single study. A study conducted in the United States by Biraglia and Kadile (2017), however, revealed that self-efficacy mediated the influence of creativity on the entrepreneurship inclination of home brewers in the country. Hence, the current study builds on the study by Biraglia and Kadile (2017) by striving to determine if self-efficacy mediates the effect of the technological creativity on the entrepreneurial intentions of South African university of technology students. Thus, the current study hypothesises that:

$\mathbf{H}_{3}$ : Self-efficacy mediates the relationship between the technological creativity and entrepreneurial intentions.

\section{Research methodology \\ Research design}

The study was informed by a positivist world view and therefore adopted a quantitative research approach. Specifically, the study used a cross-sectional survey design in order to gather precise self-reported data from multiple sources in a relatively short time. Apart from that, survey data allow for the testing of associative and predictive relationships between independent variables and dependent variables.

\section{Target population}

The target population of this study were tertiary students exposed to entrepreneurship education who can be conceived as potential entrepreneurs. Students from various faculties at a particular university of technology in South Africa constituted the sampling frame. The students had completed a preliminary subject in entrepreneurship and therefore were considered to have a range of career options. These were individuals on the brink of making critical career choices on whether to pursue formal employment or entrepreneurship. The researchers chose university students as the target population, because the goal of the study was not to establish the actual entrepreneurial behaviour of respondents but rather entrepreneurship intentions. Thus, established business owners were inappropriate subjects. Because the study was based on self-reports of students, the researchers cannot guarantee the durability of the entrepreneurial intentions of these respondents.

Although technological creativity is embedded in the domain of science and technology, this is not exclusive. Thus, students from across various disciplines were targeted. The study was concerned with students in faculties where entrepreneurship is directly taught and where one of the expected outcomes of instruction is to generate entrepreneurial intentions.

\section{Sampling plan}

The original sample contained 200 randomly selected students, with 70 failing to return the questionnaires allotted to them. The sample was picked from a sampling frame of class lists using an online random number generator. The sampling frames included learners from business, applied sciences, humanities and engineering disciplines. The sample size of 200 was chosen in order to enhance the likelihood of normal distribution of data and mitigate the effects of non-response. A rule of thumb is that a data set of 30 elements or more is potentially normally distributed and, therefore, gives results that are generalisable (Saunders, Lewis \& Thornhill 2009).

\section{Measuring instrument}

A self-completion questionnaire consisting of close-ended questions only was used for data collection. Section A items concerned demographic aspects, while section B had Likertscale items with scores ranging from 1 (strongly disagree) to 5 (strongly agree). The measures for technological creativity were adopted from Ndofirepi (2016). In Ndofirepi's (2016) study, the variable had good reliability as shown by the Cronbach's alpha index of 0.850 . The entrepreneurship intention measures were adopted from the study by Liñán and Chen (2009), in which the scale had good reliability as shown by the Cronbach's alpha score of 0.943 . 
The measuring scale for self-efficacy was adapted from Forbes (2005), where the previous application of the scale items had high internal consistency as shown by the Cronbach's alpha score of 0.850 .

\section{Control factors}

Several attempts have been made to assess the relationship between personal factors and students' entrepreneurship intentions (Chaudhary 2017; Feder \& Niţu-Antonie 2017; Herman \& Stefanescu 2017; Karimi et al. 2017). Some studies propose a positive connection between entrepreneurship intention and factors such as exposure and past entrepreneurship experiences (McCann 2017; Miralles, Giones \& Riverola 2016; Zapkau, Schwens \& Kabst 2017). Some scholars also argue that the exposure of individuals to entrepreneurship increases the likelihood of participating in entrepreneurial activity in the later stages of life (Pfeifer et al. 2016; Shamsudin et al. 2017). The preceding argument follows a high occurrence of entrepreneurial activity among individuals whose parents have been self-employed or whose families own and manage a business enterprise (Altinay et al. 2012; Henley 2007). Therefore, one's proximity to entrepreneurial role models has a positive influence on one's entrepreneurship intentions.

Results from other studies point towards differences in the entrepreneurship intentions of students on the basis of age (Law \& Breznik 2016), gender (Santos, Roomi \& Liñán 2016; Tsai, Chang \& Peng 2016), level of education attained (Dehghanpour Farashah 2013; Venugopal, Viswanathan \& Jung 2015) and marital status (Thorgren et al. 2016). Also, ethnicity and culture, through their influence on risk tolerance behaviour among certain population groups, affected the entrepreneurial intentions of individuals (Krueger, Liñán \& Nabi 2013; Urban \& Ratsimanetrimanana 2015). Because of the support they receive from the social networks found in their ethnic groups and the natural inclination of particular ethnic or cultural groups towards entrepreneurship, some individuals have relatively higher entrepreneurial intentions compared to others.

While some of the preceding factors were included in the study as control variables, the influence of culture and ethnicity was excluded as the majority of students were predominantly from one ethnic group. Apart from that, students often adopt hybrid identities as they transition to universities, which further complicate the determination of the influence of cultural identity on entrepreneurial intentions. The control factors were measured using selfdeveloped close-ended questions where respondents had to tick applicable responses for each item.

\section{Reliability and validity measures}

The reliability of the three variables in the current study was established using the Cronbach's alpha test. The outcomes are presented in Table 1.
TABLE 1: Reliability test results.

\begin{tabular}{lcc}
\hline Variable & Number of items & Cronbach's alpha value \\
\hline Technological creativity & 12 & 0.881 \\
Self-efficacy & 16 & 0.914 \\
Entrepreneurship intention & 6 & 0.926 \\
\hline
\end{tabular}

According to George and Mallery (2016), a Cronbach's alpha score that is greater than 0.8 shows good internal consistency of scale items. In addition, a reliability score that is greater than 0.9 demonstrates excellent internal consistency of a scale. Therefore, the reliability test results for variables used in the current study showed a degree of reliability that ranged from good to excellent.

Although pre-validated scales were used for the three study variables, the researchers assessed the questionnaire items for construct validity using exploratory factor analysis. The Kaiser-Meyer-Olkin (KMO) measure of sampling and Bartlett's test of sphericity were performed to establish the suitability of the data for factor analysis. The KMO measure of sampling adequacy score of 0.841 obtained was greater than the cut-off point of 0.5 while the outcome of the Bartlett's test of sphericity, that is, $x^{2}(561)=2654.655$, $p<0.000$, shows that the pattern of correlation of the items on the scales was compact and could yield reliable factors. An orthogonal rotation (varimax) was performed on the 34 items of the measuring scale using principal component analysis as the extraction method. Three factors (technological creativity, self-efficacy and entrepreneurship intention) emerged, based on Kaiser's benchmark on how to determine the number of factors in the scale to maintain, and these explained $52.934 \%$ of the variance. Accordingly, the satisfactory loading of all 34 items on three factors shows convergent validity. Table 2 presents the factor loadings after rotation.

\section{Data analysis}

The researchers used SPSS 23 to conduct descriptive procedures and inferential statistics on the collected data. In addition, the following tests were performed on the data in order to answer the research questions: frequency, Pearson's correlation test, regression analysis and the bootstrapping procedure for assessing mediation effects put forth by Preacher and Hayes (2008). The results are presented in the ensuing discussion.

Table 3 shows the demographic details of the respondents of the study. As reflected in Table 3, most of the respondents $(89.69 \%)$ had attained a degree or diploma qualification, while the remainder had lesser qualifications. Furthermore, the majority of respondents $(85.38 \%)$ in this study came from business courses with the remainder drawn from Applied sciences, Humanities, Engineering and other disciplines. Apart from that, the majority of respondents $(74.62 \%)$, as represented by the total of 'never married', 'divorced' and 'widowed', were single. Only 35.38\% were married. The results on the respondents' age distribution indicated that the majority of respondents were older than 
TABLE 2: Exploratory factor analysis results.

\begin{tabular}{|c|c|c|c|}
\hline \multirow[t]{2}{*}{ Variables } & \multicolumn{3}{|c|}{ Component } \\
\hline & 1 & 2 & 3 \\
\hline $\begin{array}{l}\text { I am ready to do anything to become an } \\
\text { entrepreneur }\end{array}$ & - & - & 0.694 \\
\hline $\begin{array}{l}\text { My professional goal is to become an } \\
\text { entrepreneur }\end{array}$ & - & - & 0.843 \\
\hline $\begin{array}{l}\text { I will make every effort to start and run my own } \\
\text { business }\end{array}$ & - & - & 0.879 \\
\hline I am determined to create a business in the future & - & - & 0.901 \\
\hline I have a serious thought of starting a business & - & - & 0.879 \\
\hline $\begin{array}{l}\text { I have a firm intention of starting a business } \\
\text { someday }\end{array}$ & - & - & 0.827 \\
\hline $\begin{array}{l}\text { I believe I can identify some business } \\
\text { opportunities }\end{array}$ & 0.630 & - & - \\
\hline $\begin{array}{l}\text { I believe I can create ways to improve business } \\
\text { and products }\end{array}$ & 0.635 & - & - \\
\hline $\begin{array}{l}\text { I believe I can create products and services that } \\
\text { meet the needs of customers }\end{array}$ & 0.675 & - & - \\
\hline I believe I can successfully develop new businesses & 0.711 & - & - \\
\hline I believe I can think creatively & 0.738 & - & - \\
\hline I believe I can inspire others & 0.667 & - & - \\
\hline I believe I can conduct market analysis & 0.723 & - & - \\
\hline I believe I can formulate a set of actions & 0.680 & - & - \\
\hline $\begin{array}{l}\text { I believe I can identify financing opportunities for } \\
\text { business }\end{array}$ & 0.603 & - & - \\
\hline I believe I can identify a good management team & 0.671 & - & - \\
\hline I believe I can build a good management team & 0.714 & - & - \\
\hline I believe I can build business relationships & 0.633 & - & - \\
\hline I believe I can tolerate unexpected change & 0.652 & - & - \\
\hline I believe I can persist in the face of setbacks & 0.621 & - & - \\
\hline I believe I can work productively under pressure & 0.560 & - & - \\
\hline I believe I can successfully start own business & 0.441 & - & - \\
\hline $\begin{array}{l}\text { I usually consider more than one solution to } \\
\text { address a problem in my day-to-day activities }\end{array}$ & - & 0.421 & - \\
\hline I enjoy trying out new ideas in my daily activities & - & 0.524 & - \\
\hline $\begin{array}{l}\text { I purposefully seek problems where nobody else } \\
\text { sees any }\end{array}$ & - & 0.577 & - \\
\hline $\begin{array}{l}\text { I always adopt new ways of doing things even if I } \\
\text { am not sure about the outcome }\end{array}$ & - & 0.719 & - \\
\hline $\begin{array}{l}\text { I am willing to try an original, new technology- } \\
\text { supported method even if there is a chance it } \\
\text { could fail }\end{array}$ & - & 0.736 & - \\
\hline $\begin{array}{l}\text { I have purposefully mastered some creativity } \\
\text { techniques, e.g. brainstorming }\end{array}$ & - & 0.756 & - \\
\hline $\begin{array}{l}\text { I easily make connections between trends in the } \\
\text { technological environment and opportunities for } \\
\text { improvement in my life }\end{array}$ & - & 0.727 & - \\
\hline $\begin{array}{l}\text { When brainstorming for ideas, I am quick to air my } \\
\text { view that something will not be practical or } \\
\text { plausible }\end{array}$ & - & 0.727 & - \\
\hline $\begin{array}{l}\text { I love to modify and adapt my daily routines in line } \\
\text { with new technology }\end{array}$ & - & 0.716 & - \\
\hline $\begin{array}{l}\text { I am continually looking for new technology-driven } \\
\text { ideas to make life easier }\end{array}$ & - & 0.715 & - \\
\hline $\begin{array}{l}\text { Once I have developed a technology-supported } \\
\text { plan, I am prepared to stick to it }\end{array}$ & - & 0.619 & - \\
\hline $\begin{array}{l}\text { I continuously look at old problems with a fresh } \\
\text { mindset guided by the latest technology } \\
\text { developments }\end{array}$ & - & 0.628 & - \\
\hline
\end{tabular}

21 years old, with the 21-30 years age group contributing $45 \%$ while the $31-40$ years age group contributed $40 \%$ of the responses. There was an uneven distribution of respondents on the basis of gender as women constituted the majority $(58.46 \%)$ while men made up the remainder $(41.54 \%)$. Also, at least $63.85 \%$ of the respondents were linked to someone who was an entrepreneur while $36.15 \%$ were not. Lastly, a minority of the respondents
TABLE 3: Demographic profile of respondents.

\begin{tabular}{|c|c|c|}
\hline Variables & Frequency & Percentage \\
\hline \multicolumn{3}{|c|}{ Highest qualification level } \\
\hline Tertiary certificate & 11 & 8.46 \\
\hline Diploma or degree & 114 & 87.69 \\
\hline Other & 5 & 3.85 \\
\hline Total & 130 & 100.00 \\
\hline \multicolumn{3}{|l|}{ Current field of study } \\
\hline Applied sciences & 3 & 2.31 \\
\hline Business & 111 & 85.38 \\
\hline Humanities & 5 & 3.85 \\
\hline Engineering & 3 & 2.31 \\
\hline Other & 8 & 6.15 \\
\hline Total & 130 & 100.00 \\
\hline \multicolumn{3}{|l|}{ Marital status } \\
\hline Never married & 73 & 56.15 \\
\hline Married & 46 & 35.38 \\
\hline Divorced or separated & 10 & 7.69 \\
\hline Widowed & 1 & 0.77 \\
\hline Total & 130 & 100.00 \\
\hline \multicolumn{3}{|l|}{ Age } \\
\hline Below 21 & 5 & 3.85 \\
\hline Between 21 and 30 & 58 & 44.62 \\
\hline Between 31 and 40 & 52 & 40.00 \\
\hline Between 41 and 50 & 14 & 10.77 \\
\hline More than 51 years & 1 & 0.77 \\
\hline Total & 130 & 100.00 \\
\hline \multicolumn{3}{|l|}{ Gender } \\
\hline Male & 54 & 41.54 \\
\hline Female & 76 & 58.46 \\
\hline Total & 130 & 100.00 \\
\hline \multicolumn{3}{|c|}{ Proximity to entrepreneurs } \\
\hline Yes & 83 & 63.85 \\
\hline No & 47 & 36.15 \\
\hline Total & 130 & 100.00 \\
\hline \multicolumn{3}{|c|}{ Prior exposure to entrepreneurship } \\
\hline Yes & 59 & 45.38 \\
\hline No & 71 & 54.62 \\
\hline Total & 130 & 100.00 \\
\hline
\end{tabular}

TABLE 4: Correlation test results.

\begin{tabular}{lccc}
\hline Variables & Self-efficacy & $\begin{array}{c}\text { Technological } \\
\text { creativity }\end{array}$ & $\begin{array}{c}\text { Entrepreneurship } \\
\text { intention }\end{array}$ \\
\hline Self-efficacy & 1 & $0.372^{* *}$ & $0.461^{* *}$ \\
Pearson's correlation & - & 0.000 & 0.000 \\
Significance level (2-tailed) & 130 & 130 & 130 \\
$N$ & & & \\
Technological creativity & $0.372^{* *}$ & 1 & $0.195^{*}$ \\
Pearson's correlation & 0.000 & - & 0.035 \\
Significance level (2-tailed) & 130 & 130 & 130 \\
$N$ & & & 1 \\
Entrepreneurship intention & $0.461^{* *}$ & $0.195 *$ & - \\
Pearson's correlation & 0.000 & 0.035 & 130 \\
Significance level (2-tailed) & 130 & 130 & \\
$N$ & & & \\
\hline
\end{tabular}

*, correlation is significant at the $5 \%$ level (2-tailed); $* *$, correlation is significant at the $1 \%$ level (2-tailed).

$(45.38 \%)$ had prior exposure to entrepreneurship while $54.62 \%$ did not.

Table 4 provides the results of the test for correlation among self-efficacy, technological creativity and entrepreneurship intention. 
TABLE 5: Multiple regression analysis results.

\begin{tabular}{|c|c|c|c|c|c|}
\hline Entrepreneurship intentions & Coefficient & Standard error & $t$ & $p$ & $95 \%$ Confidence interval \\
\hline Self-efficacy & 0.272 & 0.063 & 4.28 & 0.000 & 0.1468 to 0.398 \\
\hline Technological creativity & 0.005 & 0.076 & 0.07 & 0.942 & -0.145 to 0.156 \\
\hline Gender & -1.726 & 0.943 & -1.83 & 0.070 & -3.597 to 0.145 \\
\hline Age & -0.383 & 0.687 & -0.56 & 0.579 & -1.746 to 0.980 \\
\hline Marital status & 0.817 & 0.748 & 1.09 & 0.277 & -0.666 to 2.301 \\
\hline Highest educational qualification attained & 0.703 & 1.459 & 0.48 & 0.631 & -2.191 to 3.599 \\
\hline Prior exposure to entrepreneurship & -2.930 & 0.969 & -3.02 & 0.003 & -4.852 to -1.007 \\
\hline constant & 12.881 & 7.732 & 1.67 & 0.099 & -2.452 to 28.214 \\
\hline
\end{tabular}

Note: $F(8104)=6.686, p<0.001, R^{2}=0.35$.

$p$, denotes calculated probability; $t$, denotes the test statistic for comparing group means.

The outcomes of the Pearson's correlation test reveal that the three variables were positively and significantly interconnected. The study uses Cohen's (1988) scale of effect sizes to evaluate the strength of both negative and positive relationships. According to the scale, coefficients between 0.10 and 0.29 represent a weak relationship. Those between 0.30 and 0.49 denote a moderate relationship, while those greater than 0.50 indicate a strong relationship (Cohen 1988). Therefore, the correlation between technological creativity and self-efficacy was moderate and positive $(r=0.372$, $n=130, p<0.000$ ), that between technological creativity and entrepreneurship intention was weak and positive ( $r=0.195, n=130, p>0.035)$ and the one between self-efficacy and entrepreneurship intention was moderate and positive $(r=0.461, n=130, p<0.000)$.

Multiple regression analysis was used to determine if technological creativity and self-efficacy predicted the entrepreneurship intentions of respondents when personal factors are controlled. Preliminary analyses were performed to prevent any violation of the assumptions of normality, linearity and homoscedasticity. The outcomes of the preliminary analyses were concomitant with the assumptions of multiple regression analysis. The results of the test are provided in Table 5.

The results from Table 5 depict that the multiple linear regression model was significant with approximately $35 \%$ of the variance in entrepreneurial intention being explained by some of the imputed independent variables. Of these independent variables, only self-efficacy and prior exposure to entrepreneurship had a significant effect on entrepreneurship intentions as indicated by their $p$-values which are less than 0.05 . The beta coefficient for self-efficacy was 0.27 , which means that a unit change in self-efficacy causes a 0.27 unit change in entrepreneurship intentions. Finally, the beta coefficient for prior exposure to entrepreneurship was -2.93 . This means that a unit change in prior exposure to entrepreneurship brings about a -2.93 unit change in entrepreneurship intentions.

A mediation analysis guided by Preacher and Hayes' (2004, 2008) bootstrapping procedure was performed in order to investigate whether self-efficacy mediated the effect of technological creativity on entrepreneurship intention.
This was done using a computational tool called the Hayes' (2017) PROCESS macro that uses an ordinary least squares regression-based path analytical framework to estimate direct and indirect effects in a mediation model. Initially, separate linear regression tests were conducted to check for the predictive effect of, firstly, technological creativity and, secondly, self-efficacy on the entrepreneurship intentions of students. The results showed that technological creativity was a significant predictor of entrepreneurship intention $(b=0.161$, standard error $[\mathrm{SE}]=0.077, p<0.05)$ and that self-efficacy also had a significant predictive effect on entrepreneurship intention $(b=0.329, \mathrm{SE}=0.064, p<0.05)$.

The results of the initial test satisfied the conditions for testing a mediational relationship. Consequently, the two independent variables (technological creativity and selfefficacy) were included in the same regression equation to test if they collectively predicted entrepreneurship intentions. The outcome revealed that approximately $22.3 \%$ of the variance in entrepreneurship intentions was accounted for by the predictors $(R=0.223)$. However, technological creativity was not a significant predictor $(b=0.25, \mathrm{SE}=0.075$, $p=0.734)$ of entrepreneurship intentions after including the proposed mediator, self-efficacy. Such an outcome suggested a mediated relationship between the predictor variables.

The procedure explained in the above paragraph offers incomplete evidence of the existence of mediation, hence the need for further proof to confirm the existence of such mediation. As a result, there was a need to assess this proposed mediated relationship by testing the hypothesised effects using a bootstrap estimation approach with 5000 samples. Box 1 presents the results of the test.

For the indirect effect coefficient to be significant, the bootstrap lower- and upper-level confidence intervals must not include zero. As can be seen from Box 1, the indirect effect coefficient was significant, $b=0.136, \mathrm{SE}=0.0476,95 \% \mathrm{CI}=0.0571,0.2492$. This confirms mediation. The test revealed full mediation, because when the mediator (self-efficacy) is introduced, the direct effect (Technological creativity $\rightarrow$ Entrepreneurial intentions) is non-significant and the indirect effect (Technological creativity $\rightarrow$ Self-efficacy $\rightarrow$ Entrepreneurial intentions) is significant (Baron \& Kenny 1986). Thus, selfefficacy fully mediated the relationship between technological creativity and entrepreneurship intentions. 
BOX 1: Total, direct and indirect effects test results.

\begin{tabular}{|c|c|c|c|c|c|}
\hline \multicolumn{6}{|c|}{ Total effect of technological creativity on entrepreneurship intentions } \\
\hline Effect & Standard Error & $t$ & $p$ & Lower level confidence interval & Upper level confidence interval \\
\hline 0.1613 & 0.0773 & 2.0884 & 0.039 & 0.0083 & 0.3144 \\
\hline Effect & Standard Error & $t$ & $p$ & Lower level confidence interval & Upper level confidence interval \\
\hline 0.0254 & 0.0745 & 0.3407 & 0.734 & -0.1223 & 0.173 \\
\hline \multicolumn{6}{|c|}{ Indirect effect of technological creativity on entrepreneurship intentions } \\
\hline Self-efficacy & 0.136 & 0.0476 & & 0.0571 & 0.2492 \\
\hline \multicolumn{6}{|c|}{ Normal theory tests for indirect effect (Sobel test) } \\
\hline & Effect & Standard Error & & $z$ & $p$ \\
\hline & 0.136 & 0.0434 & & 3.1318 & 0.0017 \\
\hline
\end{tabular}

Note: Some cases were deleted because of missing data. The number of such cases was 15 .

Number of bootstrap samples for bias-corrected bootstrap confidence intervals: 5000 .

Level of confidence for all confidence intervals in output: $95 \%$.

$p$ denotes calculated probability; $z$ denotes the $z$-score which is the number of standard deviations from the mean

\section{Ethical consideration}

The researchers sought permission to conduct the study from the Institutional Office at the partaking university of technology, before conducting the study. One of the co-authors, with the assistance of some lecturers at the data collection station, distributed the questionnaires to respondents for completion during lectures. These were then collected soon after completion. There was no reward offered to respondents for completing the research instrument.

\section{Discussion}

The study's first objective sought to determine the significance of the linkages among the technological creativity, selfefficacy and entrepreneurship intentions of university students. The outcomes revealed positive and significant correlations between technological and entrepreneurship intentions, technological creativity and self-efficacy as well as self-efficacy and entrepreneurship intention. Yet, the effect size of the association stretched from weak to moderate.

The results on the technological creativity-entrepreneurship intentions connection corroborate the foundational research on entrepreneurship intentions which incorporates cognitive processes (Chen 2012; Fillis \& Rentschler 2010; Hamidi et al. 2008; Lourenço \& Jayawarna 2011; Sun 2012; Zampetakis 2008; Zampetakis et al. 2011). The positive but weak correlation between technological creativity and entrepreneurship intention suggests that although technological creativity may trigger recognition of entrepreneurship opportunities and drive entrepreneurship, the mere endowment with such creativity may not always translate into the actual implementation of creative ideas. Also, the fact that the results of this study revealed a fully mediating role of self-efficacy on the relationship means that despite one's technological creativity, the absence of self-efficacy may undermine the realisation of entrepreneurial intentions.

Baer (2012) emphasises the need for rigorous research into the conditions that determine when creative ideas are converted into actual innovations (i.e. use and implementation of technologically creative ideas) through entrepreneurial ventures. There is a growing realisation that although technological creativity and the implementation of technologically creative ideas are distinct phases of innovation processes (Baer 2014), technological creativity and entrepreneurship intentions could be shaped by a variety of contextual and sociocultural processes. Dzansi and ArkoAchemfuor (2016) argue that cultural factors are critical in shaping different cultural groups' behaviours, attitudes and perceptions of their capacity to bear the risk of incubating businesses even if these groups have an equal propensity to generate novel ideas.

The positive moderate correlation between self-efficacy and entrepreneurship intentions supports conclusions from the earlier studies that indicate a significant positive association between self-efficacy and the respondents' entrepreneurship intentions (Arora et al. 2013; Braun 2014; Bullough et al. 2014; Campo 2010; Drnovšek et al. 2010). Consistent with the view that individuals with high self-efficacy tend to have daring tendencies and are inclined to perform challenging tasks (Bandura 1970) and have high confidence in their abilities critical to overcoming ambiguity and risks associated with contemporary businesses (Ferreira et al. 2012; Modise 2017), it is then logical to expect the possession of self-efficacy as instrumental in breeding entrepreneurial intentions. The result also coheres with the study by Vanevenhoven and Ligori (2013) on the impact of entrepreneurship education that was based on a sample of students 70 from countries and 400 universities from across the globe. Their study reported a significant positive correlation between self-efficacy and entrepreneurial outcome expectations. Self-efficacy, which is a belief and confidence that an individual has in their own abilities to accomplish a task, is thus integral to the pursuit of entrepreneurship intentions (Hill 2016) because ventures operate in a complex climate that demands tolerance of ambiguity and the bearing of risks.

The findings which revealed a positive correlation between technological creativity and self-efficacy corroborate the finding of $\mathrm{Wu}$, Tsai and Wang (2011) concerning the 
relationship between technological creativity, self-efficacy and knowledge sharing among athletes and the mediating effect of athletes' self-efficacy on the technological creativityknowledge-sharing relationship. The findings of $\mathrm{Wu}$, Tsai and Wang (2011) demonstrated that an improvement in the athletes' self-efficacy may improve their creativity and level of technological capacity.

These results underscore the aspects which policymakers, entrepreneurship educators and stakeholders in entrepreneurship research and development need to concentrate on. Entrepreneurship education and training interventions should indeed adopt teaching and learning methods that inspire the creativity and self-efficacy of learners as these affect their inclination to participate in entrepreneurship activities in the future. There is a likelihood that the improvement of such abilities among students will produce individuals who recognise fewer obstacles to entrepreneurship, are tolerant of risk and uncertainty and disposed towards trying out business ideas and pursuing prospects.

The study also sought to determine if technological creativity and self-efficacy predicted entrepreneurship intentions when personal factors were controlled. The multiple regression model used proved the predictive effect of selfefficacy and prior exposure to entrepreneurship only as these had significant beta coefficients. This is because while the overall model was significant, the coefficients for control variables were insignificant. This demonstrates that only self-efficacy and prior exposure to entrepreneurship were significant predictors even in the presence of other variables (controlled for). The outcome relating to the positive and significant predictive effect of self-efficacy on entrepreneurship intentions supports the finding of Joensuu et al. (2014) that self-efficacy beliefs (in addition to support of the immediate environment and attitudes towards entrepreneurial careers) appear as the most relevant factor explaining entrepreneurial intentions. In addition, Pihie and Bagher (2013) found that students' entrepreneurial selfefficacy has the most significant and positive impact on their intention to become an entrepreneur while entrepreneurial self-efficacy highly affects students' entrepreneurial intention both directly and indirectly. This finding, however, seems to be inconsistent with the mediating role of entrepreneurial self-efficacy on the influence of entrepreneurship education on the formation of entrepreneurial intentions (Sanchez 2011). A further finding which revealed a significant but negative effect of prior exposure to entrepreneurship on entrepreneurial intentions suggests that those exposed to entrepreneurship (e.g. those who witnessed the high failure rate of their families and role models' businesses) may be less predisposed to taking entrepreneurship pursuits seriously (Hsu et al. 2017; Wyrwich, Stuetzer \& Sternberg 2016). Perhaps such individuals may be wary of the complexities of entrepreneurship arising from their possible lack of tolerance for ambiguity and resource constraints that may undermine the success of businesses during their first stages of existence. In fact, self-efficacy features prominently in explanations of the relationship between prior entrepreneurial experiences and entrepreneurial intention, with Hsu et al. (2017:19) suggesting that 'failure undermines self-efficacy if individuals attribute the cause of failure to themselves and hence may prompt him or her to shy away from subsequent entrepreneurial ventures'.

The study also sought to establish whether self-efficacy mediates the link between technological creativity and students' entrepreneurship intentions. The results substantiated that self-efficacy fully mediates the stated relationship. This result closely resembles the observation by Biraglia and Kadile (2017) that self-efficacy accounted for a significant degree of change in the relationship between general creativity and entrepreneurship intentions of individuals. Apart from attesting the need for self-efficacy for individuals to engage in entrepreneurial careers, it reveals that the sole possession of creative abilities may be inadequate to eliminating students' perceptions of obstacles to and risks associated with entrepreneurship. In addition, the results give credence to the assertion by the Bandura's (1970) Social Learning Theory that self-efficacy underlies all premeditated behaviour. Finally, the study outcomes imply that technological creativity, taken in isolation, is a weak predictor of entrepreneurship intention. Thus, technologically creative characters need to first believe in their capabilities before they can express their preparedness to take part in entrepreneurship. This builds on the study by Zampetakis et al. (2011) which, although specifically not targeting technological creativity, established that the more creative university students conceived themselves to be, the higher their entrepreneurial intentions.

\section{Conclusions and managerial implications}

The results of this study stress the need to integrate cognitive variables, such as self-efficacy and technological creativity in entrepreneurship intention models. Evidence from both the current study and the extant literature underscore that a factor like technological creativity, through its focus on real-life or practical problem solving, a strong orientation towards improving productivity and emphasis on the role of environmental influences or contextual influences contributes to enhancing entrepreneurial intentions and new venture creation. The implication for practice is that entrepreneurship educators in higher education institutions should incorporate technological creativity and stimulation of self-efficacy in their curricula if they are to nurture potential entrepreneurs. The case for such a course of action is strengthened by the fact that incessant contextual changes in the business environment render traditional entrepreneurship education methods ineffective. Consequently, there is a need for innovative approaches to help entrepreneurs to counter the new challenges. This can be done by introducing in entrepreneurship classes individual and group learning activities that encompass complex problem identification and problem solving (e.g. through simulation-based learning). Simulations and problem-based learning create 
authentic scenarios that enhance participants' abilities to generate a greater number and range of ideas and solutions to real problems (Schmidt, Soper \& Bernaciak 2013). Thus, the entrepreneurship curriculum should offer more than the technical aspects of new venture creation and management.

The phenomenon of incorporating creativity-related components in entrepreneurship education in higher education is still new and presents the challenge of locating the individuals who will be responsible for teaching such courses. This demonstrates the need for designing dedicated programmes for training the trainers (educators) in preparation for the teaching of entrepreneurship and technological creativity. Such programmes should provide these educators with the necessary teaching and learning aids needed for the effective teaching of the revamped courses.

\section{Limitations and suggestions for future research}

The findings from this study might not be generalisable to students at other South African institutions given the relatively small student sample used and the study's focus on a single university of technology. Thus, future studies should integrate learners from comparable institutions to augment the representativeness of the sample. In addition, targeting university students only limits the generalisability of the findings as they do not represent the whole population of potential entrepreneurs, and therefore, other learners at various high schools and other training colleges should be included in future studies.

In addition, the composition of the sample was biased towards the university's Faculty of Management as noted in the way that most of the respondents (85.38\%) were sourced from the faculty. Thus, the technical and other non-management disciplines at the university were under-represented in the sample, although they also educate entrepreneurs. This stated limitation suggests that future studies should use all-inclusive samples from respondents who represent the various study fields being undertaken by the students.

Lastly, the study's quantitative character may have led to the neglect of more enlightening and richer data, which a qualitative approach could have generated had it been merged in the study. Accordingly, future studies can explore the same topic as the current study using a mixed-method approach in order to enhance the breadth of the research results.

\section{Acknowledgements}

This article is an expanded version of a paper presented by the authors at the First International Conference on Entrepreneurship Development held at the Central University of Technology, Free State (South Africa), in April 2017.

\section{Competing interests}

The authors declare that they have no financial or personal relationships that may have inappropriately influenced them in writing this article.

\section{Authors' contributions}

T.M.N. was the project leader and wrote the article. P.R. and D.Y.D. were responsible for the research design, language and formatting aspects.

\section{References}

Ahuja, A., 2016, 'A study of self-efficacy among secondary school students in relation to educational aspiration and academic achievement', Educational Quest 7(3), 275-283. https://doi.org/10.5958/2230-7311.2016.00048.9

Ajzen, I., 1991, 'The theory of planned behavior', Organizational Behavior and Human Decision Processes 50(2), 179-211. https://doi.org/10.1016/07495978(91)90020-T

Ajzen, I., 2015, 'Consumer attitudes and behavior: The theory of planned behavior applied to food consumption decisions', Rivista di Economia Agraria 70(2), 121-138.

Altinay, L., Madanoglu, M., Daniele, R. \& Lashley, C., 2012, 'The influence of family tradition and psychological traits on entrepreneurial intention', International Journal of Hospitality Management 31(2), 489-499. https://doi.org/10.1016/j. ijhm.2011.07.007

Amabile, T.M. \& Pratt, M.G., 2016, 'The dynamic componential model of creativity and innovation in organizations: Making progress, making meaning', Research in Organizational Behavior 36, 157-183. https://doi.org/10.1016/j.riob.2016.10.001

Arora, P., Haynie, J.M. \& Laurence, G.A., 2013, 'Counterfactual thinking and entrepreneurial self-efficacy: The moderating role of self-esteem and dispositional affect', Entrepreneurship: Theory and Practice 37(2), 359-385. https://doi. org/10.1111/j.1540-6520.2011.00472.x

Asah, F., Fatoki, O.O. \& Rungani, E., 2015, 'The impact of motivations, personal values and management skills on the performance of SMEs in South Africa', African Journal of Economic and Management Studies 6(3), 308-322. https://doi. Journal of Economic and Manager
org/10.1108/AJEMS-01-2013-0009

Baer, J., 2014, Creativity and divergent thinking: A task-specific approach, Psychology Press, New York.

Baer, M., 2012, 'Putting creativity to work: The implementation of creativity ideas in organizations', Academy of Management Journal 55(5), 1102-1110. https://doi. org/10.5465/amj.2009.0470

Bandura, A., 1970, 'Modelling theory: Some traditions, trends, and disputes', in W. Sahakian (ed.), Psychology of learning: Systems, models, and theories, pp. 35-61, Markham, Chicago, IL.

Baron, R.M. \& Kenny, D.A., 1986, 'The moderator-mediator variable distinction in social psychological research: Conceptual, strategic, and statistical considerations', Journal of Personality and Social Psychology 51(6), 1173.

Becherer, R.C. \& Helms, M.M., 2016, 'The role of entrepreneurial marketing in improving market share for small businesses facing external environmental or resource challenges', Journal of Business and Entrepreneurship 27(2), 119-147.

Berglund, H. \& Wennberg, K., 2006, 'Creativity among entrepreneurship students: Comparing engineering and business education', International Journal of Continuing Engineering Education and Life-Long Learning 16(5), 366-379. https:// doi.org/10.1504/IJCEELL.2006.010959

Bhalla, A.S. \& Lapeyre, F., 2016, Poverty and exclusion in a global world, Palgrave MacMillan, London.

Biraglia, A. \& Kadile, V., 2017, 'The role of entrepreneurial passion and creativity in developing entrepreneurial intentions: Insights from American home-brewers' Journal of Small Business Management 55(1), 170-188. https://doi.org/10.1111/ jsbm.12242

Bird, B., 1988, 'Implementing entrepreneurial ideas: The case for intention', Academy of Management Review 13(3), 442-453.

Bird, B., 2015, 'Entrepreneurial intentions research: A review and outlook', International Review of Entrepreneurship 13(3), 143-168.

Botha, M. \& Bignotti, A., 2016, 'Internships enhancing entrepreneurial intent and selfefficacy: Investigating tertiary-level entrepreneurship education programmes', The Southern African Journal of Entrepreneurship and Small Business Management 8(1), 1-15. https://doi.org/10.4102/sajesbm.v8i1.45

Braun, F.C., 2014, 'Entrepreneurial self-efficacy, intent and intensity: Does experiential training enhance or inhibit predisposition?', Journal of Developmenta Entrepreneurship 19(1), 1-22.

Bullough, A., Renko, M. \& Myatt, T., 2014, 'Danger zone entrepreneurs: The importance of resilience and self-efficacy for entrepreneurial intentions', Entrepreneurship: Theory \& Practice 38(3), 473-499. https://doi.org/10.1111/ etap.12006

Camacho-Miñano, M.D.M. \& Del Campo, C., 2017, 'The role of creativity in entrepreneurship: An empirical study on business undergraduates', Education + Training 59(7/8), 672-688. https://doi.org/10.1108/ET-08-2016-0132 
Campo, J.L.M., 2010, 'Analysis of the influence of self-efficacy on entrepreneurial intentions', Prospectiva 9(2), 14-21.

Cant, M.C. \& Wiid, J.A., 2013, 'Establishing the challenges affecting South African SMEs', The International Business \& Economics Research Journal (Online) 12(6), 707-716. https://doi.org/10.19030/iber.v12i6.7869

Charyton, C., 2008, Creativity (scientific, artistic, general) and risk tolerance among engineering and music students, VDM-Verlag, Saarbrücken, Germany.

Chaudhary, R., 2017, 'Demographic factors, personality and entrepreneurial inclination: A study among Indian university students', Education + Training 59(2), 171-187. https://doi.org/10.1108/ET-02-2016-0024

Chen, J.C.I., 2012, 'Critical creativity criteria for students in higher education: Taking the interrelationship effect among dimensions into account', Quality \& Quantity 46(4), 1057-1075. https://doi.org/10.1007/s11135-011-9448-7

Chuang, S.P. \& Huang, S.J., 2016, 'The effect of environmental corporate socia responsibility on environmental performance and business competitiveness: The mediation of green information technology capital', Journal of Business Ethics. Advance online publication. https://doi.org/10.1007/s10551-016-3167-x

Cohen, J., 1988, 'Set correlation and contingency tables', Applied Psychological Measurement 12(4), 425-434. https://doi.org/10.1177/014662168801200410

Cropley, D. \& Cropley, A., 2010, 'Recognizing and fostering creativity in technological design education', International Journal of Technology and Design Education 20(3), 345-358. https://doi.org/10.1007/s10798-009-9089-5

Cui, A.S. \& Wu, F., 2017, 'The impact of customer involvement on new product development: Contingent and substitutive effects', Journal of Product Innovation Management 34(1), 60-80. https://doi.org/10.1111/jpim.12326

Dean, T., Griffith, D.A. \& Calantone, R.J., 2016, 'New product creativity: Understanding contract specificity in new product introductions', Journal of Marketing 80(2), 39-58. https://doi.org/10.1509/jm.14.0333

Dehghanpour Farashah, A., 2013, 'The process of impact of entrepreneurship education and training on entrepreneurship perception and intention: Study of educational system of Iran', Education + Training 55(8/9), 868-885. https://doi. org/10.1108/ET-04-2013-0053

Dinis, A., Paço, A., Ferreira, J., Raposo, M. \& Rodrigues, R.G., 2013, 'Psychological characteristics and entrepreneurial intentions among secondary students', Education + Training 55(8/9), 1-23. https://doi.org/10.1108/ET-06-2013-0085

Drnovsek, M. \& Erikson, T., 2005, 'Competing models of entrepreneurial intentions', Economic and Business Review for Central and South-Eastern Europe 7(1), 55-71.

Drnovšek, M., Wincent, J. \& Cardon, M.S., 2010, 'Entrepreneurial self-efficacy and business start-up: Developing a multi-dimensional definition', International Journal of Entrepreneurial Behavior \& Research 16(4), 329-348. https://doi org/10.1108/13552551011054516

Dzansi, D. \& Arko-Achemfuor, A., 2016, 'Understanding entrepreneurship in the South African context: Insights from entrepreneurship risk attitudes of four large ethic groups', African Journal of Science, Technology, Innovation and Development 8(2), 146-154. https://doi.org/10.1080/20421338.2016.1147199

Fayolle, A., 2013, 'Personal views on the future of entrepreneurship education', Entrepreneurship \& Regional Development: An International Journal 25(7-8), 692-701. https://doi.org/10.1080/08985626.2013.821318

Fayolle, A. \& Liñán, F, 2014, 'The future of research on entrepreneurial intentions', Journal of Business Research 67(5), 663-666. https://doi.org/10.1016/j. jbusres.2013.11.024

Fayolle, A., Liñán, F. \& Moriano, J.A., 2014, 'Beyond entrepreneurial intentions: Values and motivations in entrepreneurship', International Entrepreneurship and Management Journal 10(4), 679-689. https://doi.org/10.1007/s11365-014 0306-7

Feder, E.S. \& Niţu-Antonie, R.D., 2017, 'Connecting gender identity, entrepreneurial training, role models and intentions', International Journal of Gender and Entrepreneurship 9(1), 87-108. https://doi.org/10.1108/IJGE-08-2016-0028

Ferreira, J.J., Fayolle, A., Fernandes, C. \& Raposo, M., 2017, 'Effects of Schumpeterian and Kirznerian entrepreneurship on economic growth: Panel data evidence', Entrepreneurship \& Regional Development 29(1-2), 27-50. https://doi.org/10.10 80/08985626.2016.1255431

Ferreira, J.J., Raposo, M.L., Rodrigues, R.G., Dinis, A. \& Paço, A.D., 2012, 'A model of entrepreneurial intention: An application of the psychological and behavioral approaches', Journal of Small Business and Enterprise Development 19(3), 424440. https://doi.org/10.1108/14626001211250144

Fillis, I. \& Rentschler, R., 2010, 'The role of creativity in entrepreneurship', Journa of Enterprising Culture 18(01), 49-81. https://doi.org/10.1142/S02184958 10000501

Forbes, D.P., 2005, 'The effects of strategic decision making on entrepreneurial selfefficacy', Entrepreneurship Theory and Practice 29(5), 599-626. https://doi. org/10.1111/j.1540-6520.2005.00100.x

George, D. \& Mallery, P., 2016, IBM SPSS statistics 23 step by step: A simple guide and reference, Routledge, London.

Griffiths, M., Kickul, J., Bacq, S. \& Terjesen, S., 2012, 'A dialogue with William J. Baumol: Insights on entrepreneurship theory and education', Entrepreneurship: Baumol: Insights on entrepreneurship theory and education', Entrepreneurship:
Theory and Practice 36(4), 611-625. https://doi.org/10.1111/j.1540-6520.2012. Theory and
00510.x

Hamidi, D.Y., Wennberg, K. \& Berglund, H., 2008, 'Creativity in entrepreneurship education', Journal of Small Business and Enterprise Development 15(2), 304-320. education', Journal of Small Business and Enterpris
Hatak, I. \& Snellman, K., 2017, 'The influence of anticipated regret on business startup behaviour', International Small Business Journal 35(3), 349-360. https://doi. org/10.1177/0266242616673421

Hattab, H.W., 2014, 'Impact of entrepreneurship education on entrepreneurial intentions of university students in Egypt', Journal of Entrepreneurship 23(1), 1-18. https://doi.org/10.1177/0971355713513346

Hayes, A.F., 2017, Introduction to mediation, moderation, and conditional process analysis: A regression-based approach, Guilford Publications, New York.

Henley, A., 2007, 'Entrepreneurial aspiration and transition into self-employment Evidence from British longitudinal data', Entrepreneurship and Regional Development 19(3), 253-280. https://doi.org/10.1080/08985620701223080

Herman, E. \& Stefanescu, D., 2017, 'Can higher education stimulate entrepreneurial intentions among engineering and business students?', Educational Studies 43(3), 312-327. https://doi.org/10.1080/03055698.2016.1277134

Herrington, M., Kew, P. \& Mwanga, A., 2017, South Africa report: Can small businesses survive in South Africa? Global Entrepreneurship Monitor, Cape Town.

Hill, S., 2016, 'Entrepreneurial characteristics in STEM: A higher education institution perspective', in I. Aaltio \& M. Eskelinen (eds.), Proceedings of the 11th European Conference on Innovation and Entrepreneurship, The JAMK University of Applied Sciences, Jyväskylä, Finland, September 15-16, 2016, pp. 265-272.

Hsu, D.K., Wiklund, J. \& Cotton, R.D., 2017, 'Success, failure, and entrepreneurial reentry: An experimental assessment of the veracity of self-efficacy and prospect theory', Entrepreneurship Theory and Practice 41(1), 19-47. https://doi.org/ 10.1111/etap.12166

Joensuu, S., Varamäki, E., Viljamaa, A., Heikkilä, T. \& Katajavirta, M., 2014, Entrepreneurial thinking, change in entrepreneurship thinking and factors affecting them during the training, Seinäjoki University of Applied Sciences Publication Series A. Studies, Seinäjoki Polytechnic, Seinäjoki.

Karimi, S., Biemans, H.J., Naderi Mahdei, K., Lans, T., Chizari, M. \& Mulder, M., 2017 'Testing the relationship between personality characteristics, contextual factors and entrepreneurial intentions in a developing country', International Journal of Psychology 52(3), 227-240. https://doi.org/10.1002/ijop.12209

Krueger, Jr, N.F., 2000, 'The cognitive infrastructure of opportunity emergence', Entrepreneurship Theory and Practice 24(3), 5-23.

Krueger, Jr, N.F. \& Brazeal, D.V., 1994, 'Entrepreneurial potential and potential entrepreneurs', Entrepreneurship Theory and Practice 18(3), 91104.

Krueger, N., Liñán, F. \& Nabi, G., 2013, 'Cultural values and entrepreneurship', Entrepreneurship \& Regional Development 25(9-10), 703-707. https://doi.org/10 1080/08985626.2013.862961

Krueger, N.F., Reilly, M.D. \& Carsrud, A.L., 2000, 'Competing models of entrepreneurial intentions', Journal of Business Venturing 15(5), 411-432. https://doi.org/10.1016/ S0883-9026(98)00033-0

Law, K.M. \& Breznik, K., 2016, 'Impacts of innovativeness and attitude on entrepreneurial intention: Among engineering and non-engineering students', International Journal of Technology and Design Education 27 (4), 683-700.

Lin, J. \& Nabergoj, A.S., 2014, 'A resource-based view of entrepreneurial creativity and its implications to entrepreneurship education', Economic and Business Review, 16(2), 163-183.

Liñán, F. \& Chen, Y.W., 2009, 'Development and cross-cultural application of a specific instrument to measure entrepreneurial intentions', Entrepreneurship Theory and Practice 33(3), 593-617. https://doi.org/10.1111/j.1540-6520.2009.00318.x

Liñán, F. \& Fayolle, A., 2015, 'A systematic literature review on entrepreneurial intentions: Citation, thematic analyses, and research agenda', International Entrepreneurship and Management Journal 11(4), 907-933. https://doi.org/ 10.1007/s11365-015-0356-5

Lourenço, F. \& Jayawarna, D., 2011, 'Enterprise education: The effect of creativity on training outcomes', International Journal of Entrepreneurial Behaviour \& Research 17(3), 224-244. https://doi.org/10.1108/13552551111130691

Lund, M., Byrge, C., \& Nielsen, C., 2017, 'From creativity to new venture creation: A conceptual model of training for original and useful business modelling', Journal conceptual model of training for origin
of Innovation and Creativity, 3, 66-88.

Maduku, D.K., Mpinganjira, M. \& Duh, H., 2016, 'Understanding mobile marketing adoption intention by South African SMEs: A multi-perspective framework',

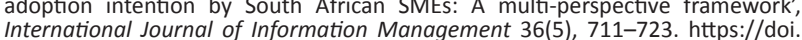
International Journal of Information
org/10.1016/j.ijinfomgt.2016.04.018

Malebana, M., 2014, 'The relationship between exposure to entrepreneurship education and entrepreneurial self-efficacy', Southern Africa Business Review $18(1), 1-26$

Malebana, M.J. \& Swanepoel, E., 2015, 'Graduate entrepreneurial intentions in the rural provinces of South Africa', Southern Africa Business Review 19(1), 89-111.

Martin, L. \& Wilson, N., 2016, 'Opportunity, discovery and creativity: A critical realist perspective', International Small Business Journal 34(3), 261-275. https://doi. org/10.1177/0266242614551185

Mauer, R., Neergaard, H. \& Linstad, A.K., 2009, 'Self-efficacy: Conditioning the entrepreneurial mindset', in A. Carsrud \& M. Brännback (eds.), Understanding the entrepreneurial mind: Opening the black box, pp. 233-256, Springer, Heidelberg.

McCann, B.T., 2017, 'Prior exposure to entrepreneurship and entrepreneurial beliefs', International Journal of Entrepreneurial Behavior \& Research 23(3), 591-612. https://doi.org/10.1108/IJEBR-05-2016-0160

McElwee, G. \& Atherton, A., 2005, 'Publication trends and patterns in entrepreneurship: The case of the International Journal of Entrepreneurship and Innovation', Journa of Small Business and Enterprise Development 12(1), 92-103. https://doi. org/10.1108/14626000510579662 
McGee, J.E. \& Peterson, M., 2017, 'The long-term impact of entrepreneurial selfefficacy and entrepreneurial orientation on venture performance', Journal of Small Business Management, Advance online publication. https://doi. org/10.1111/jsbm.12324

Miralles, F., Giones, F. \& Riverola, C., 2016, 'Evaluating the impact of prior experience in entrepreneurial intention', International Entrepreneurship and Management Journal 12(3), 791-813. https://doi.org/10.1007/s11365-015-0365-4

Modise, D., 2017, 'Technological literacy, open innovation, and self-efficacy on entrepreneurship readiness: A case of selected CUT University students' perspectives', Masters Proposal, Faculty of Management Studies, CUT.

Mokyr, J., 1992, The lever of riches: Technological creativity and economic progress, Oxford University Press, Gary, NC.

Nabi, G., Holden, R. \& Walmsley, A., 2010, 'Entrepreneurial intentions among students: Towards a re-focused research agenda', Journal of Small Business and Enterprise Development 17(4), 537-551. https://doi.org/10.1108/1462600 1011088714

Nabi, G., Liñan, F., Fayolle, A., Krueger, N. \& Walmsley, A., 2017, 'The impact of entrepreneurship education in higher education: A systematic review and research agenda', Academy of Management Learning \& Education 16(2), 277299. https://doi.org/10.5465/amle.2015.0026

Ndofirepi, T.M., 2016, 'The impact of technological creativity and entrepreneurship education on the entrepreneurship intentions of students at particular tertiary institutions in Zimbabwe and South Africa', PhD thesis, Central University of Technology, Bloemfontein.

Ng, T.W. \& Lucianetti, L., 2016, 'Within-individual increases in innovative behavior and creative, persuasion, and change self-efficacy over time: A social-cognitive theory perspective', Journal of Applied Psychology 101(1), 14-34. https://doi.org/ 10.1037/apl0000029

Nowiński, W., Haddoud, M.Y., Lančarič, D., Egerová, D. \& Czeglédi, C., 2017, 'The impact of entrepreneurship education, entrepreneurial self-efficacy and gender on entrepreneurial intentions of university students in the Visegrad countries',
Studies in Higher Education. Advance online publication. https://doi.org/10.1080/ Studies in Higher Education

Pacey, A., 2014, 'Technology: Practice and culture', in R.S. Sandler (eds.), Ethics and emerging technologies, pp. 27-36, Palgrave Macmillan, London.

Peng, Z., Lu, G. \& Kang, H., 2012, 'Entrepreneurial intentions and its influencing factors: A survey of the university students in Xi'an China', Creative Education 3 95-100. https://doi.org/10.4236/ce.2012.38B021

Pfeifer, S., Šarlija, N. \& Zekić Sušac, M., 2016, 'Shaping the entrepreneurial mindset: Entrepreneurial intentions of business students in Croatia', Journal of Small Business Management 54(1), 102-117. https://doi.org/10.1111/jsbm.12133

Pihie, Z. \& Bagheri, A., 2013, 'Self-efficacy and entrepreneurial intention: The mediation effect of self-regulation', Vocations and Learning 6(3), 385-401. https://doi.org/10.1007/s12186-013-9101-9

Piperopoulos, P. \& Dimov, D., 2015, 'Burst bubbles or build steam? Entrepreneurship education, entrepreneurial self-efficacy, and entrepreneurial intentions', Journa of Small Business Management 53(4), 970-985. https://doi.org/10.1111/ jsbm.12116

Prajogo, D.I., 2016, 'The strategic fit between innovation strategies and business environment in delivering business performance', International Journal of Production Economics 17(1), 241-249. https://doi.org/10.1016/j.ijpe.2015. 07.037

Preacher, K.J. \& Hayes, A. F., 2004, 'SPSS and SAS procedures for estimating indirect effects in simple mediation models', Behavior Research Methods, Instruments, \& Computers 36(4), 717-731.

Preacher, K.J. \& Hayes, A.F., 2008, 'Asymptotic and resampling strategies for assessing and comparing indirect effects in multiple mediator models', Behavior Research Methods 40(3), 879-891. https://doi.org/10.3758/BRM.40.3.879

Rambe, P., Ndofirepi, T.M. \& Dzansi, D.Y., 2015, 'Influence of entrepreneurial education and technological creativity on entrepreneurial intentions of students in Zimbabwe: A theoretical perspective', in 10th European Conference on Innovation and Entrepreneurship, Genoa, September 17-18, pp. 576-588.

Rambe, P., Ndofirepi, T.M. \& Dzansi, D.Y., 2016, 'Technological creativity and its influence on entrepreneurship intentions of vocational education', in Proceedings of the 11th European Conference on Innovation and Entrepreneurship, The JAMK University of Applied Science, Jyväskylä, Finland, September 15-16, 2016, pp. University of App

Rumble, R. \& Minto, N.A., 2017, 'How to use analogies for creative business modelling', Journal of Business Strategy 38(2), 76-82. https://doi.org/10.1108/JBS-09-20160091

Sanchez, J.C., 2011, 'University training for entrepreneurial competencies: Its impact on intention of venture creation', The International Entrepreneurship and Management Journal 7(2), 239-254. https://doi.org/10.1007/s11365-0100156-x

Santos, F.J., Roomi, M.A. \& Liñán, F., 2016, 'About gender differences and the social environment in the development of entrepreneurial intentions', Journal of Small Business Management 54(1), 49-66. https://doi.org/10.1111/jsbm.12129

Saunders, M., Lewis, P. \& Thornhill, A., 2009, Research methods for business students, 4th edn., Pearson Education Limited, Harlow.

Schlaegel, C. \& Koenig, M., 2014, 'Determinants of entrepreneurial intent: A metaanalytic test and integration of competing models', Entrepreneurship Theory and Practice 38(2), 291-332. https://doi.org/10.1111/etap.12087

Schmidt, J.J., Soper, J.C. \& Bernaciak, J., 2013, 'Creativity in the entrepreneurship program: A survey of the directors of award winning programs', Journal of Entrepreneurship Education 16(1), 31-45.
Schumpeter, J.A., 1934, The theory of economic development: An inquiry into profits, capital, credit, interest, and the business cycle, vol. 55, Transaction Publishers, Piscataway.

Shamsudin, S.F.F.B., Mamun, A.A., Nawi, N.B.C., Nasir, N.A.B.M. \& Zakaria, M.N.B., 2017, 'Factors influencing entrepreneurial intention and the moderating role of entrepreneurship education: A conceptual model', Advanced Science Letters 23(4), 3006-3008. https://doi.org/10.1166/asl.2017.7635

Shapero, A. \& Sokol, L., 1982, 'The social dimensions of entrepreneurship', in C. Kent, D. Sexton \& K. Vesper (eds.), The encyclopedia of entrepreneurship, pp. 72-90, Prentice-Hall, Englewood Cliffs, NJ.

Singh, B., Verma, P. \& Rao, M.K., 2017, 'Influence of individual and socio-cultural factors on entrepreneurial intention', in M. Manimala and P. Thomas (eds.), Entrepreneurship Education, pp. 149-169, Springer, Singapore.

Solesvik, M.Z., 2017, 'A cross-national study of personal initiative as a mediator between seff-efficacy and stu of East-West Business 23(3), 215-237. https://doi.org/10.1080/10669868.201 7.1306821

Statistics South Africa, 2017, Quarterly Labour Force Survey - QLFS Q3:2017, Statssa. gov.za, viewed 04 December 2017, from http://www.statssa.gov.za/?p=10658

Sun, H., 2012, 'The PIPE model for teaching creativity, innovation and entrepreneurship', Teaching, Assessment, and Learning for Engineering, TALE 2012 3(2), 159-166. https://doi.org/10.1109/TALE.2012.6360369

Sweida, G.L. \& Reichard, R.J., 2013, 'Gender stereotyping effects on entrepreneurial self-efficacy and high-growth entrepreneurial intention', Journal of Small Business and Enterprise Development 20(2), 296-313. https://doi.org/10.1108/ 14626001311326743

Thompson, E.R., 2009, 'Individual entrepreneurial intent: Construct clarification and development of an internationally reliable metric', Entrepreneurship Theory and Practice 33(3), 669-694. https://doi.org/10.1111/j.1540-6520. 2009.00321.x

Thorgren, S., Sirén, C., Nordström, C. \& Wincent, J., 2016, 'Hybrid entrepreneurs' second-step choice: The nonlinear relationship between age and intention to enter full-time entrepreneurship', Journal of Business Venturing Insights 5, 14-18. https://doi.org/10.1016/j.jbvi.2015.12.001

Toubia, O. \& Netzer, O., 2016, 'Idea generation, creativity, and prototypicality', Marketing Science 36(1), 1-20. https://doi.org/10.1287/mksc.2016.0994

Tsai, K.H., Chang, H.C. \& Peng, C.Y., 2016, 'Refining the linkage between perceived capability and entrepreneurial intention: Roles of perceived opportunity, fear of failure, and gender', International Entrepreneurship and Management Journal 12(4), 1127-1145. https://doi.org/10.1007/s11365-016-0383-x

Urban, B., 2015, 'Evaluation of social enterprise outcomes and self-efficacy', International Journal of Social Economics 42(2), 163-178. https://doi.org/ 10.1108/IJSE-03-2013-0071

Urban, B. \& Ratsimanetrimanana, F.A., 2015, 'Culture and entrepreneurial intentions of Madagascan ethnic groups', Journal of Entrepreneurship in Emerging Economies 7(2), 86-114. https://doi.org/10.1108/JEEE-01-2015-0008

Urban, B., Van Vuuren, J.J. \& Owen, R.H., 2008, 'Antecedents to entrepreneurial intentions: Testing for measurement invariance for cultural values, attitudes and self-efficacy beliefs across ethnic groups', SA Journal of Human Resource Management 6(1), 1-9. https://doi.org/10.4102/sajhrm.v6i1.132

Utami, C.W., 2017, 'Attitude, subjective norms, perceived behavior, entrepreneurship education and self-efficacy toward entrepreneurial intention university student in Indonesia', European Research Studies 20(2), 475-495.

Vanevenhoven, J. \& Liguori, E., 2013, 'The impact of entrepreneurship education: Introducing the entrepreneurship education project', Journal of Small Business Management 51(3), 316-328. https://doi.org/10.1111/jsbm.12026

Van Gelderen, M., Brand, M., Poutsma, E. \& Van Gils, A., 2008, 'Explaining entrepreneurial intentions by means of the theory of planned behaviour', Career Development International 13(6), 538-559. https://doi.org/10.1108/136204 30810901688

Venugopal, S., Viswanathan, M. \& Jung, K., 2015, 'Consumption constraints and entrepreneurial intentions in subsistence marketplaces', Journal of Public Policy \& Marketing 34(2), 235-251. https://doi.org/10.1509/jppm.14.181

Wang, J.H., Chang, C.C., Yao, S.N. \& Liang, C., 2016, 'The contribution of selfefficacy to the relationship between personality traits and entrepreneurial intention', Higher Education 72(2), 209-224. https://doi.org/10.1007/s10734015-9946-y

Wu, C.-S., Tsai, L.-F. \& Wang, P.-W., 2011, 'Correlation between technological creativity, self-efficacy and knowledge sharing among athletes', International Journal of Management and Marketing Research 4(2), 77-84.

Wyrwich, M., Stuetzer, M. \& Sternberg, R., 2016, 'Entrepreneurial role models, fear of failure, and institutional approval of entrepreneurship: A tale of two regions', Small Business Economics 46(3), 467-492. https://doi.org/10.1007/s11187-0159695-4

Wyse, D. \& Spendlove, D., 2007, 'Partners in creativity: Action research and creative partnerships', Education 35(2), 181-191.

Yu, C., 2013, 'The relationship between undergraduate students' creative self-efficacy, creative ability and career self-management', International Journal of Academic Research in Progressive Education and Development 2(2), 181-193.

Zampetakis, L., Gotsi, M., Andriopoulos, C. \& Moustakis, V., 2011, 'Creativity and entrepreneurial intention in young people: Empirical insights from business school students', Entrepreneurship and Innovation 12(3), 189-199. https://doi. org/10.5367/ijei.2011.0037 
Zampetakis, L.A., 2008, 'The role of creativity and proactivity on perceived entrepreneurial desirability', Thinking Skills and Creativity 3, 154-162. https://doi. org/10.1016/j.tsc.2008.07.002

Zampetakis, L.A. \& Moustakis, V., 2006, 'Linking creativity with entrepreneurial intentions: A structural approach', The International Entrepreneurship and Management Journal 2(3) 413-428. https://doi.org/10.1007/s11365-0060006-
Zapkau, F.B., Schwens, C. \& Kabst, R., 2017, 'The role of prior entrepreneurial exposure in the entrepreneurial process: A review and future research implications', Journal
of Small Business Management 55(1), 56-86. https://doi.org/10.1111/jsbm.12232

Zimbroff, A., Taylor, A. \& Houser, C., 2016, 'Assessment of learning outcomes and attitude changes from experiential entrepreneurship education', in United States Association for Small Business and Entrepreneurship. Conference Proceedings, United States Association for Small Business and Entrepreneurship, San Diego, CA January $10-12,2016$ 